\title{
Geothermal energy for heating
}

\author{
Darya Zimnukhova, Galina Zubkova and Ekaterina Kamchatova* \\ State University of Management, Ryazansky Prospect, 99, Moscow, Russia
}

\begin{abstract}
This study examines issues related to the use of modern renewable energy sources and environmentally friendly minerals for the production of heat and electricity. The paper presents the principle of operation of a modern geothermal plant, which produces thermal energy for heating, in addition, an analysis of the costs of implementing projects in the field of heating with geothermal energy is carried out and presents the advantages and disadvantages of using geothermal energy. The work conducted domestic and foreign experience of using geothermal heating systems, which allowed the authors of the study to draw conclusions about the promise of introducing such technologies everywhere, due to which the electric power industry will reduce the burden on the consumption of organic fuels and increase the ecological and energy security of the regions. At the end of the work, the main conclusions on the results of the study were made.
\end{abstract}

\section{Introduction}

The earth has unlimited heat potential, estimated by scientists at about $840 \mathrm{GW}$ of electrical energy, one of the types of fuel to energy conversion is geothermal energy. Geothermal energy allows not only obtaining clean energy, but also significantly reducing the consumption of traditional fossil resources such as oil, gas and coal. According to expert estimates, $10 \mathrm{MW}$ of generated electricity at geothermal power plants saves about 140 barrels of crude oil per year. Taking into account the growth in prices for resources, as well as their exhaustibility, it should be noted that the future is behind the development of alternative energy, in particular, geothermal energy.

In addition to the generated electricity, geothermal energy can be used as a heating system for buildings and private cottages, as well as air conditioning systems and hot water [1;2].

\section{Materials and methods}

The purpose of this study is to analyze geothermal energy, as part of the electric power complex and the possibility of using geothermal energy for heating systems of residential and public buildings. To achieve this goal, we have proposed the following tasks:

- analyze the principles of the geothermal installation; - to develop measures for the development of geothermal energy for heating systems [3; 4].

The study was based on the methods of factor, comparative, statistical, logical, and economicmathematical and system analysis, the method of expert estimates, which allowed forming measures for the development of geothermal energy for heating systems $[5 ; 6]$.

\section{Results}

A complex of equipment that performs heating based on the thermal energy of the earth is called a geothermal installation, which includes 3 main elements:

- heat exchange circuit or heating circuit. The geothermal source of thermal energy, which takes heat directly from the ground, acts as a heating circuit. The temperature of the soil is usually about $+6-10$ degrees Celsius and remains unchanged throughout the year;

- heating circuit, located in the building and represents the classic heating radiators or heated floors;

- pumping system consisting of a heat pump pumping a coolant in a closed loop $[7 ; 8]$.

The principle of operation of the heating system, based on geothermal energy, is similar to the work of a simple refrigeration unit and runs through the classical Carnot cycle.

To do this, a heat pump is installed in the building or basement, and a heat exchanger is placed in the ground through which coolant circulates. Basically, water acts as a coolant. A heat pump is a device that extracts lowgrade heat from the ground and converts it into heat suitable for heating and hot water supply. To visualize the principle of operation of a heat pump, refer to the diagram presented in Figure 1 [9]. 


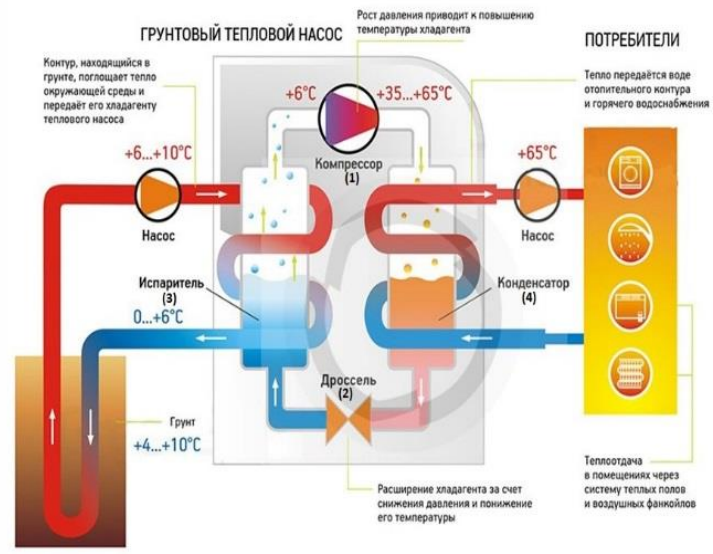

Fig. 1. The principle of operation of the ground heat pump

In the figure there is a closed circuit in which the refrigerant is driven by the compressor (1). The expansion valve (2) relating to the pumping system divides the closed loop into an area with high (right) and low (left) pressure. Thanks to this valve, the following physical law is triggered: with increasing pressure by the compressor, the temperature of the circulating refrigerant increases, and with decreasing pressure, its temperature decreases. The refrigerant is supplied to the evaporator (3) under pressure, where evaporation occurs due to a sharp increase in pressure. At the same time, the refrigerant takes heat from the inner walls of the evaporator, which heats up, in turn, from the hot coolant, which is heated in the depths of the ground. From the evaporator, the refrigerant in a gaseous state enters the compressor, where it is compressed and pushed into the condenser (4). Due to compression, its temperature rises. In the condenser, the heated refrigerant transfers the resulting heat to the heating circuit and finally goes into a liquid state. This process will be repeated until it reaches the required room temperature or in the heating circuit. Only in this case the thermostat opens the electrical circuit and the compressor stops. When the temperature in the heating circuit decreases, the thermostat switches the compressor back on and the process resumes [10].

Thus, the pump pumps low potential thermal energy of the earth into high potential heat for heating objects.

In the summer, the heat pump works in a similar way to cool the building, only this time the heat is removed from the building and, cooled in the bowels of the earth, returns to the room, thereby lowering the temperature in it.

Methods for the implementation of geothermal heating. There are 3 ways to implement geothermal heating. The key difference between these methods lies in the location of the heat exchange circuit (heating circuit). In this case, the contours have an absolute identity from a technological point of view:

- vertical heat exchanger. This type of heat exchanger requires drilling wells to a depth of 70 to 200 meters. The vertical heat exchanger occupies a small area, which allows you to leave the landscape intact and install a geothermal installation almost anywhere. However, the drilling of such deep wells requires special equipment and significant cash costs;
- horizontal heat exchanger. For laying pipes of a horizontal heat exchanger, it is necessary to dig special trenches below the level of ground freezing to avoid icing of the coolant. The horizontal heat exchanger occupies significant areas for its placement. For example, for heating a building with an area of about 250 square meters, an area of 600 square meters is necessary, which equates to a fully-fledged summer cottage. This type of accommodation is quite laborious and involves a large amount of land work, which is why it is carried out at the stage of construction or improvement of the building and the surrounding area. It should be noted that in connection with a significant area allocated for the placement of heat exchanger tubes of this type, the possibility of creating a horizontal heat exchanger in urban conditions is excluded;

- horizontal heat exchanger in a nearby reservoir. For this method of accommodation certain requirements must be met, in particular, a heated building must be located 100 meters from the water reservoir. In addition, the bottom of the reservoir should not freeze at low temperatures outside air. Despite the cheapness relative to the above-mentioned methods and a small area for placement, equal to about 200 square meters, the location of the horizontal heat exchanger in the reservoir is practically not encountered.

However, it should be noted that in spite of the above effects, achieved from the use of a geothermal installation for heating objects, this type of heating is extremely rare. The main reason for this is the significant capital expenditures at the initial stage of operation associated with the purchase of the basic necessary equipment, its installation, drilling a vertical well, or carrying out land works for trenches to house the heat exchanger. It should also be borne in mind that the cost of equipment and its installation directly depend on the power of the units, which, in turn, depends on the area of the heated room.

Approximate costs for the implementation of a geothermal heating system for a building of 150 square meters are presented in Table 1.

Table 1. Capital investment in geothermal heating

\begin{tabular}{|c|c|c|}
\hline Name of equipment / work & \begin{tabular}{|l} 
With \\
vertical heat \\
exchanger
\end{tabular} & $\begin{array}{c}\text { With } \\
\text { horizontal heat } \\
\text { exchanger }\end{array}$ \\
\hline \multicolumn{3}{|c|}{ Equipment and basic work } \\
\hline $\begin{array}{l}\text { Heat pump, internal circuit } \\
\text { circulation pump, control } \\
\text { device, high and low pressure } \\
\text { relays, phase control relays }\end{array}$ & $\begin{array}{c}347700 \\
\text { rubles }\end{array}$ & $\begin{array}{c}347700 \\
\text { rubles }\end{array}$ \\
\hline $\begin{array}{l}\text { Analogue remote control unit } \\
\text { with temperature sensor, brine } \\
\text { filling unit, external circuit } \\
\text { circulating pump, pipelines, } \\
\text { valves and fittings, wiring } \\
\text { equipment }\end{array}$ & $\begin{array}{c}493465 \\
\text { rubles }\end{array}$ & $\begin{array}{c}439085 \\
\text { rubles }\end{array}$ \\
\hline $\begin{array}{l}\text { Installation works: installation, } \\
\text { piping of a heat pump and a } \\
\text { combined tank, installation of a } \\
\text { salt solution filling unit, } \\
\text { installation of auxiliary } \\
\text { equipment, crimping and filling } \\
\text { of the internal circuit, }\end{array}$ & $\begin{array}{l}70000 \\
\text { rubles }\end{array}$ & $\begin{array}{l}70000 \\
\text { rubles }\end{array}$ \\
\hline
\end{tabular}




\begin{tabular}{|c|c|c|}
\hline \multicolumn{3}{|l|}{ commissioning works } \\
\hline \multicolumn{3}{|c|}{ Equipment and installation of the external circuit } \\
\hline & \begin{tabular}{|c|} 
Technical \\
details: \\
total contour \\
depth: 150 \\
meters
\end{tabular} & $\begin{array}{c}\text { Technical } \\
\text { details: - total } \\
\text { contour length: } \\
300 \mathrm{~m} \text { - pipe } \\
\text { laying depth: } \\
1.6 \mathrm{~m} \text { - } \\
\text { Orientation } \\
\text { laying area: } 300 \\
\text { squares. m }\end{array}$ \\
\hline $\begin{array}{l}\text { Distribution manifold, pipes, } \\
\text { external circuit coolant, other } \\
\text { consumables }\end{array}$ & 87080 rubles & 87080 rubles \\
\hline $\begin{array}{l}\text { Excavation: } \\
\text { Trench gaskets, pipe laying, } \\
\text { installation of a distribution } \\
\text { manifold, laying of a horizontal } \\
\text { part of a contour, punching } \\
\text { holes, thermal insulation of a } \\
\text { contour, waterproofing of pipes. }\end{array}$ & - & 172080 rubles \\
\hline $\begin{array}{l}\text { Drilling, excavation, } \\
\text { commissioning, installation of a } \\
\text { distribution manifold, laying of } \\
\text { the vertical part of the contour, } \\
\text { punching holes, waterproofing } \\
\text { pipes. }\end{array}$ & 300000 rubles & - \\
\hline Total: & $\begin{array}{c}1244245 \\
\text { rubles }\end{array}$ & 1116325 rubles \\
\hline
\end{tabular}

Thus, for heating a 150-square-meter building, an initial cash investment of 1.1-1.2 million rubles will be required. However, these capital costs will be recouped within 6-8 years, with the continuous operation of the geothermal installation as a heating system during the cold season, as well as an air-conditioning system during the summer period.

To compare the efficiency of using various systems of private heating, we will conduct a comparative analysis of the cost of $1 \mathrm{MJ}$ of heat received from different energy sources (Table 2):

Table 2. Comparative analysis of the cost of $1 \mathrm{MJ}$ at various energy sources

\begin{tabular}{|c|c|}
\hline Power source & Cost of 1 MJ \\
\hline Electricity & 1.05 rubles \\
\hline Liquefied gas & 24 kopecks \\
\hline Diesel fuel & 1.06 rubles \\
\hline Heat pump & 17 kopecks \\
\hline
\end{tabular}

- electric heating. Electric heating of a private house can be represented in the form of heaters operating on the network, heating boilers, as well as under floor heating, powered by electricity. To generate $3.6 \mathrm{MJ}$ requires 1 $\mathrm{kWh}$ of electricity, the cost of which depends on the region in which the building is located. For the Moscow region, $1 \mathrm{kWh}$ is 3.77 rubles. It turns out that the cost of $1 \mathrm{MJ}$ will be equal to 1.05 rubles;

- gas heating. This type of heating is represented by gas boilers burning a liquefied or main gas;

- trunk. When it is impossible to connect the house to the gas pipeline, they resort to the use of liquefied petroleum gas. When burning $1 \mathrm{~kg}$ of liquefied gas, $41 \mathrm{MJ}$ of heat is generated. The cost of $1 \mathrm{~kg}$ of gas -10 rubles $/ \mathrm{kg}$, therefore, the cost of $1 \mathrm{MJ}$ of heat produced will be 24 kopecks;

- heating with diesel fuel. This method of heating is presented as a boiler, working on diesel fuel. The specific heat of combustion of diesel fuel is $43.4 \mathrm{MJ}$ per $1 \mathrm{~kg}$. The cost of diesel fuel is 45.9 rubles per $\mathrm{kg}$. It turns out that the cost of $1 \mathrm{MJ}$ of heat generated from the combustion of diesel fuel is 1.06 rubles;

- geothermal heating, working with an electric heat pump. When $1 \mathrm{~kW}$ of electricity is consumed by a heat pump, $6 \mathrm{kWh}$ of heat is generated, which is $21.6 \mathrm{MJ}$, considering that $1 \mathrm{~kW}$ of electrical energy is equal to 3.6 MJ of heat. From the calculation of the cost of electricity for the Moscow region of 3.77 rubles per $1 \mathrm{kWh}$, the cost of $1 \mathrm{MJ}$ of heat received from the use of a geothermal installation will not exceed 18 kopecks.

From the calculations made it can be seen that the use of heat pumps is the most cost-effective way to heat the objects. However, at the moment the most widespread gas heating due to its availability and low cost [11].

However, there are both advantages and disadvantages from the use of geothermal energy. One of the main advantages of the geothermal heating system is high efficiency, as the heat pump produces about 6 kilowatts of thermal energy, while consuming 1 kilowatt of electricity. For comparison, in electric heating systems, the cost of 1 kilowatt of electrical energy transforms only from 0.7 to 1.0 kilowatt of heat [12].

It is worth noting the safety of using a geothermal heating system due to the fact that the design of the heat pump is not explosive and flammable fuels. In addition to safety, geothermal heating is distinguished by its environmental friendliness. The use of the system is not accompanied by gas leaks, emissions of pollutants into the atmosphere, and there is no smoke and smell in the rooms.

This system is easy to operate and maintain due to the high degree of automation, and the pumps require minimal maintenance and work fairly quietly, without creating extraneous noise and without causing discomfort to humans [13]. Also, consumers will not have to pay extra for the heat they receive from the ground, and the life of the heat pump is more than 25 years, which determines the longevity of the system.

However, despite the inexhaustible thermal energy of the soil, the organization of geothermal heating presents many difficulties and disadvantages.

First, the disadvantages of using a geothermal heating system include the high cost of the equipment itself and a long payback period. So, equipment for geothermal heating costs at least 10 times more expensive than gas equipment of similar capacity, and the payback period may exceed 10-15 years, 2-3 times longer than the payback period of a domestic gas boiler [13]. In addition, it is necessary to consider the costs of creating and arranging underground utilities. Thus, geothermal heating system is inferior in its financial indicators to traditional gas, electric or solid fuel heating.

Secondly, there is a dependence of the work of the geothermal system on electrical energy. After all, to obtain approximately 4 kilowatts of thermal energy, at 
least 1 kilowatt of electrical energy is necessary. Since the heat is not taken from the ground spontaneously, the use of a pump is necessary. In case of power outages, the pump stops working, therefore, the heating circuit also stops providing the consumer with heat.

Thirdly, due to overcooling of the soil at the location of the thermal collector, the system may be disturbed. However, this usually happens only because of mistakes made in the design [12].

Finally, fourth, it is worth noting the limitations of the application. A geothermal heating system may not be installed on every object of consumption. Heating a separate apartment in a high-rise building in the central district of the city, for example, is rendered impossible, since it is not allowed to develop soil in densely populated areas. Of course, for the organization of heating on the territory of the housing object from the private sector or enterprise on the outskirts of the city it is possible to use a geothermal heating system.

In the Russian Federation in recent years began to introduce geothermal energy for heating systems. As an example of the use of a geothermal heating system in Russia, the system used in a school in the suburb of Barnaul, Altai Krai will be considered. The basis of the power industry of the Altai Territory are thermal power plants, the total installed electrical and thermal capacity of which is 1,655 MW and 6,731 Gcal / hr, respectively. This capacity covers only half of the required amount of electrical energy, the rest it receives from the Unified Energy System of Siberia, which explains the high cost of electricity [15].

In this regard, the region is actively developing and introducing renewable energy sources to compensate for the lack of electricity in the region. For example, in the village of Lebyazhye in the suburb of Barnaul because of the impossibility of connecting the school building to the municipal coal boiler and the economic inexpediency of building a gas boiler for the school, the city authorities decided to heat the building with geothermal energy from a depth of 25 meters. In this region, this is the first project of a geothermal heating system implemented in a public institution.

To implement the project, a special powerful pump was installed, pumping heat from the earth and converting it into energy suitable for heating. The principle of operation of the pump is quite simple: for 2 minutes it takes heat from the soil at a depth of 5-7 degrees, and then converts it into high-grade thermal energy, and it comes to the system already with a temperature of about 50 degrees. In the summer, a recovery process takes place: the system gives off heat to the earth due to the passive conditioning of the school [16].

However, the heat of the earth turned out to be lowtemperature and is able to heat radiators up to a maximum of 35-36 degrees. Therefore, to maintain a comfortable temperature of 22 degrees in the room, the school building was carefully insulated. The following were made as insulators: foam glass, insulated doors and seven-dimensional double-glazed windows on the windows.
Modernization of the building and construction of engineering systems cost the city budget about 18 million rubles. However, it is assumed that these investments will pay off in the next 7 years, given the previous monthly expenses for electric heating of 1.3 million rubles [17]. There are successful examples of the use of geothermal heating in private homes, livestock farms and small industrial enterprises in the Altai Territory, but the experience of using this system in Barnaul is the first for budgetary organizations.

Thus, the successful experience of using geothermal energy in Barnaul is the best solution for heating similar budget organizations in the region. However, for the widespread use of geothermal energy, both in the Altai Territory and in the country as a whole, a well-developed legislative framework is needed, as well as state support.

Geothermal heating technology has been effectively used for decades in the United States, where there has been a surge in the use of heat pumps. American scientists Melissa Lapsa and Gannate Khowailed, who studied the US geothermal energy market, published the results in the Heat Pump Center. The truthfulness of the research data is confirmed by the Oak Ridge National Laboratory at the United States Department of Energy.

According to the study, more than 13 million US private homes, which is about $12 \%$ of the inhabited housing in the country, use heat pumps as the main equipment for heating. Of course, the largest share of the use of the system is observed in private homes, but this technology is also actively used in apartment buildings, and the use share is only $3 \%$ lower than in private homes. Basically, the massive installation of heat pumps takes place in the southern part of the country due to a more moderate winter. Thus, more than $82 \%$ of users, and this is about 11 million people, is concentrated in the southern United States and only $11 \%$ in the western part of the country. The temperate climate of South America makes the use of heat pumps a priority equipment for heating and cooling homes. In this region, more than $37 \%$ of private households and there is a steady increase in population [18].

The tendency to increase the use of geothermal heating systems in the United States actively influences the share of autonomous heat generation in the total heating load of the country. Since these systems are mainly used in temperate climatic zones of the United States, in homes with relatively low heating demand, they occupy about $8.3 \%$ of the total heat load of the United States, which is quite a significant indicator [19].

The heat pump market continues to grow. There is a growing increase in new buildings in the United States using this geothermal heating technology, which is associated with a decrease in electricity prices relative to natural gas in the country, as well as the energy efficiency of the system itself. About $38 \%$ of new private homes and almost half of multi-storey new buildings in the United States in 2012 were equipped with heat pumps $[19 ; 20]$. Of course, for the mass introduction of geothermal heating systems in built apartment buildings will take decades. This is due to the difficulties of replacing old heating systems with new geothermal heating systems. 
In the future, under favorable conditions, an increase in the share of geothermal energy use in the USA is expected to triple by 2040 . Geothermal heating systems are increasingly used in the cold regions of the country. In addition, heat pumps are actively used outside large cities, where access to a centralized heating infrastructure is limited. In this case, geothermal heating becomes an affordable and quite effective independent source of heat. Already today, improvements are being made to the development of geothermal heating, the search for ways to reduce the cost and increase the efficiency of systems. The high potential of applying geothermal heating technology has attracted the attention of consumers not only in the United States, but throughout the world.

\section{Conclusions}

Thus, in the framework of the study, the basic principles of heat pump operation were analyzed, thanks to which it is possible to provide industrial consumers and the population with thermal energy. The economic evaluation of the feasibility of using geothermal energy in our work led to the conclusion that this method of obtaining thermal energy is not only environmentally friendly, but also cost-effective. In addition, as part of the study, experience in the implementation of geothermal energy in the Russian Federation and in the countries of the world was considered.

\section{References}

1. V. Pulyaeva et al 2019 IOP Conf. Ser.: Mater. Sci. Eng. 537042033.

2. A. Gibadullin et al 2019 IOP Conf. Ser.: Mater. Sci. Eng. 537042065.

3. E. Kamchatova, A. Vasilieva, N. Lyasnikov, M. Dudin, N. Vysotskaya, Eneggy saving management in urban economy and industry. International Journal of Civil Engineering and Technology, 2018, vol. 9, no 6, pp. 1423-1429.

4. V. Vorontsov, A. Timofeev, F. Sharipov, Current trends in the coal market in China in the second half of 2018. Ugol', 2019, vol. 4(1117), pp. 110-112. http://dx.doi.org/10.18796/0041-5790-2019-4-110-112

5. A. Gibadullin et al 2019 IOP Conf. Ser.: Mater. Sci. Eng. 537042031

6. D.Morkovkin et al 2019 IOP Conf. Ser.: Mater. Sci. Eng. 537042064

7. N. Kharitonova, E. Kharitonova, V. Pulyaeva, Prospects for application of new information technologies in contemporary higher economic education. Advances in Intelligent Systems and Computing, 2019, vol. 726, pp. 1091-1100.

8. Underground geothermal home heating, Profiteplo, URL: $\quad$ https://profiteplo.com/sistemy-otopleniya/107geotermalnoe-otoplenie-doma-teplom-zemli.html

9. Geothermal heating: principle of operation, pros and cons, subtleties of construction, Stroy podskazka, URL: https://stroy-podskazka.ru/otoplenie/geotermalnoeotoplenie

10. The principle of operation, installation, advantages and disadvantages of geothermal heating for the house, Informational website about batteries Akbinfo, URL: https://akbinfo.ru/alternativa/geotermalnoeotoplenie.html

11. Comparison of different heating systems with the heat pump system and their application in the Kemerovo region, Proceedings of the IV International student scientific conference "Student scientific forum", URL: https://scienceforum.ru/2012/article/2012002428.

12. Geothermal home heating, Best heating of private homes, URL: https://lucheeotoplenie.ru/tipyotopleniya/geotermalnoe/geotermalnoe-otopleniedoma.html\#preimushhestva-geotermalnogo-otopleniya

13. Liquefied gas heating or geothermal heating? Intrgaz, URL: https://www.intergaz.lv/ru/geotermalnoeotoplenie-ili-shizhenij-gaz

14. Cons of geothermal heating, Otopleniesam, URL: https:/otopleniesam.ru/alternativnoe-

otoplenie/geotermalnoe-otoplenie/minusyi-

geotermalnogo-otopleniya.html

15.The electric power industry of Altai Krai, http://www.myshared.ru/slide/ 823840

16. The school of the Altai territory uses geothermal equipment for heating, URL: https://vgornom.ru/lenty/kholodnyj-belok/45159-v-shkole-

altajskogo-kraya-dlya-obogreva-ispolzuyutgeotermalnoe-oborudovanie

17. Alternative energy in Altai: opportunities and prospects,

URL:

https://ecodelo.org/rossiyskaya_federaciya/sibirskiy_fo/a ltayskiy_kray/37877-

alternativnaya_energetika_na_altae_vozmozhn

18. Geothermal heat pumps in the United States, Waters of the, URL:

https://aquatoria.kiev.ua/blog/alternativnaja-

energetika/item/112-geotermalnye-teplovye-nasosy-vssha

19. A. Gibadullin, V. Pulyaeva, Y. Yerygin, The Need for a Digital Substation during the Digitalization of Energy. International Youth Scientific and Technical Conference Relay Protection and Automation, RPA, 2018, no 8537223 .

20. A. Merenkov, Digital economy: transport management and intelligent transportation systems. Emanagement, 2018, no 1, vol. 1, pp. 12-18. DOI: 10.26425/2658-3445-2018-1-12-18. 